\title{
Pemberdayaan Wanita Tani Melalui Pengolahan Labu Kuning Menjadi Dodol Dan Roti Kasur Di Kecamatan Anggaberi
}

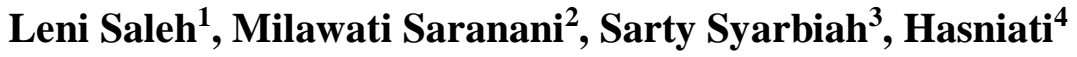 \\ 1,2,3,4 Universitas Lakidende \\ email : salehleni8@gmail.com¹, milasaranani@gmail.com², sarty_syarbiah@gmail.com³, \\ atihasniati@gmail.com ${ }^{4}$
}

\begin{abstract}
Participants in this activity are people who belong to the Kartini Mandiri Farmer Group (KWT) in the Parauna Village, Anggaberi District, Konawe Regency. Based on the objectives of the pumpkin commodity processing training activity, namely to introduce and provide additional knowledge and skills to the community regarding the technology of processing pumpkin into pumpkin lunkhead and mattress bread so that the community can develop home industries and increase the economic value of pumpkin by providing information about the benefits of pumpkin accompanied by training and practice of making dodol and pumpkin bread mattress. Processing of dodol and mattress bread with various variations of stuffing is a new innovation in Parauna Village. The successful implementation of all these community service activities certainly has quite good benefits for the community in general and for household industry players in particular.
\end{abstract}

Keywords: empowerment, women, pumpkin.

\begin{abstract}
Abstrak
Peserta dalam kegiatan ini adalah masyarakat yang tergolong dalam Kelompok Wanita Tani (KWT) Kartini Mandiri yang berada di Kelurahan Parauna Kecamatan Anggaberi Kabupaten Konawe. Berdasarkan tujuan dari kegiatan pelatihan pengolahan komoditas labu kuning yaitu memperkenalkan dan memberikan pengetahuan dan keterampilan tambahan kepada masyarakat tentang teknologi pengolahan labu kuning menjadi dodol labu kuning dan roti kasur sehingga masyarakat dapat mengembangkan industri rumah tangga dan meningkatkan nilai ekonomis dari labu kuning dengan memberikan penyuluhan tentang manfaat dari labu kuning disertai dengan pelatihan dan praktek membuat dodol dan roti kasur dari labu kuning. Pengolahan dodol dan roti kasur dengan aneka variasi isian merupakan inovasi baru di Kelurahan Parauna. Keberhasilan pelaksanaan seluruh kegiatan pengabdian kepada masyarakat ini tentunya mempunyai manfaat yang cukup baik bagi masyarakat pada umumnya dan pelaku industri rumah tangga khususnya.
\end{abstract}

Kata Kunci: pemberdayaan, wanita, labu kuning. 


\section{Pendahuluan}

Tanaman labu kuning (waluh) merupakan suatu jenis buah yang termasuk kedalam familia Cucurbitaceae, termasuk tanaman semusim yang sekali berbuah langsung mati. Labu kuning salah satu tanaman yang mudah dalam pembibitan, perawatan, dan hasilnya cukup memberikan nilai ekonomis yang tinggi kepada masyarakat. Labu kuning banyak dibudidayakan di negara Afrika, Amerika, India dan Cina. Labu kuning biasanya tumbuh pada dataran rendah maupun tinggi, ketinggian tempat antara 0-1500 meter diatas permukaan laut. Di Jawa Barat labu kuning disebut dengan "Labu Parang", karena tanaman tersebut merupakan tanaman tahunan yang menjalar (merambat) dengan perantara alat yang berbentuk pipih, batangnya cukup kuat dan panjang terdapat bulu-bulu yang agak tajam (Heliyani, 2012).

Labu kuning merupakan jenis sayuran buah yang memiliki daya awet yang tinggi, mempunyai aroma dan citarasa yang khas, serta sumber vitamin A karena kaya akan karoten. Menurut Depkes (2001), labu kuning mengandung sejumlah $1569 \mu \mathrm{g} \beta$ karoten, oleh karena itu dapat dijadikan sebagai sumber alternatif vitamin A selain wortel dan ubi jalar. Disamping itu, labu kuning juga mengandung zat gizi seperti protein, karbohidrat, beberapa mineral seperti kalsium, fosfor, besi, serta beberapa vitamin yaitu vitamin B dan C. Melihat kandungan gizinya yang cukup lengkap dan harga bahan pangan yang relatif murah, maka labu kuning ini merupakan sumber gizi yang sangat potensial untuk dikembangkan sebagai alternatif pangan masyarakat. Pada setiap 100 gram labu kuning mengandung kalori $51 \mathrm{kal}$, Air 86,6 gram, karbohidrat 10 gram, fosfor $180 \mathrm{mg}$, serat 2,7 gram, vitamin A 180 SI, vitamin B 0,08 $\mathrm{mg}$, vitamin C $2 \mathrm{mg}$ (Tabel Komposisi Pangan Indonesia, 2008).

Daging buah labu kuning yang kaya akan kandungan serat, vitamin dan mineral memiliki cita rasa sangat enak, bertekstur lembut dan dengan rasa sedikit manis cocok diolah menjadi beragam jenis pangan (Radyaswati, 2005). Labu kuning dimanfaatkan hanya dengan cara direbus (sayur dan sup) atau sebagai pangan tradisional seperti dodol, kolak, asinan, manisan, puding, kue yang termasuk makanan semi basah dengan kecenderungan memiliki umur simpan yang singkat dan distribusinya terbatas (Rahmawati et al. 2014).

Untuk menambah nilai ekonomis labu kuning, diversifikasi produk pangan, memiliki masa simpan yang lebih lama dari produk makanan semi basahnya dan agar dapat dikonsumsi sehari-hari, maka labu kuning dapat diolah menjadi makanan olahan yang lebih ekonomis bernilai tambah dan bersifat kekinian. Labu kuning merupakan buah yang masih jarang dimanfaatkan oleh industri pangan. Labu kuning memiliki daya simpan yang cukup lama, namun volumenya besar dan mudah rusak dalam pengangkutan, sehingga perlu diolah menjadi produk yang lebih tahan lama dan bernilai ekonomis. Labu kuning dapat diolah menjadi kudapan seperti dodol, kolak, roti, bolu, dan sebagainya. Salah satu bentuk pengolahan labu kuning untuk meningkatkan nilai tambahnya yaitu dengan mengolah labu kuning menjadi dodol dan roti dengan teknologi yang sederhana, mudah dan terjangkau.

Inovasi dan kreasi baru untuk mengembangkan produk labu kuning yaitu dengan mengolahnya menjadi dodol labu kuning kaya vitamin dengan tambahan susu dan menjadi roti kasur (sobek) dengan varian isi seperti cokelat, keju, cokelat keju, kacang dan selai nenas yang kekinian (millenial). Hal ini dikarenakan harga labu kuning di pasaran yang relatif murah sehingga dengan usaha dalam sajian bentuk dodol dan roti tersebut dapat dijadikan alternatif usaha baru bagi petani labu kuning di Kota Unaaha Kabupaten Konawe. Cara tersebut merupakan langkah yang efektif untuk meningkatkan pendapatan para petani khususnya wanita tani di Kabupaten Konawe. Proses pembuatan dodol labu kuning dengan sajian dalam komposisinya yang khas yaitu dengan tam- 
bahan sagu dan susu sehingga berbeda dengan dodol labu kuning lainnya dan roti kasur atau biasa disebut juga roti sobek dari labu kuning dengan variasi isian beragam dengan aneka varian isian rasa sesuai selera masyarakat dan membutuhkan waktu yang cukup singkat. Dodol labu kuning memiliki keunggulan yaitu dapat dikonsumsi oleh penderita diabetes begitu juga roti kasur ala labu kuning yang merupakan sajian tampilan kekinian.

Dodol merupakan suatu olahan pangan yang dibuat dari campuran tepung beras ketan putih, gula kelapa, santan kelapa, yang dididihkan hingga menjadi kental dan berminyak tidak lengket, dan apabila dingin pasta akan menjadi padat, kenyal dan dapat diiris. Jenis dodol sangat beragam tergantung keragaman campuran tambahan dan juga cara pembuatannya (Haryadi, 2006).

Dodol dikelompokkan menjadi 2 yaitu dodol yang berbahan dasar dari tepung, antara lain tepung beras, tepung ketan, dan dodol yang berbahan dasar dari buah-buahan. Dodol yang berbahan dasar buah, misalnya nanas, sirsak, mangga dan masih banyak lainnya. Biasanya dodol yang berbahan dasar tepung perlu penambahan essence sebagai bahan tambahan perasa, sedangkan dodol yang berbahan dasar buah hampir tidak memerlukannya. Dodol buah terbuat dari daging buah matang yang dihancurkan, kemudian dimasak dengan penambahan gula dan bahan makanan lainnya, seperti santan, tepung ketan, tepung tapioka, tepung hungkue, bahan pewarna makanan, maupun bahan pengawet (Satuhu dan Sunarmani, 2004).

Roti didefinisikan sebagai makanan yang terbuat dari tepung terigu, air, dan gula yang pada pengolahannya dilakukan proses fermentasi dan pemanggangan. Didalam ilmu pangan, roti dikelompokkan dalam produk bakery. Sama halnya seperti di belahan dunia lain, budaya makan roti juga berkembang di Indonesia (Astawan, 2005).

Salah satu jenis roti yang banyak diminati di Indonesia adalah roti kasur. Roti kasur terdiri dari beberapa potong roti kecil yang digabungkan menjadi satu sehingga berbentuk seperti kasur. Biasanya terdiri dari 6-12 potong roti yang digabungkan. Sering disebut juga sebagai roti sobek yang tidak diberi isi. Tetapi dalam kegiatan pengabdian pada masyarakat ini roti sobeknya diberi isian. untuk :

Kegiatan pengabdian ini bertujuan

1. Memberikan pengetahuan dan keterampilan dalam bentuk pelatihan tentang diversifikasi / penganekaragaman pengolahan labu kuning menjadi dodol dan roti kasur labu kuning, dengan varian isian beragam yang sesuai selera masyarakat di Kabupaten Konawe.

2. Memberikan pelatihan penerapan teknik atau metode yang dapat digunakan dalam membuat jajanan pangan lokal berbahan labu kuning kepada masyarakat agar mudah dipahami serta memiliki kualitas yang setara dengan kualitas dan bergizi karena menggunakan pangan lokal, baik dari segi rasa, tekstur dan warna, sehingga dapat layak dikonsumsi dan disukai oleh konsumen (masyarakat umum).

\section{Pelaksanaan dan Metode}

\section{Tahapan Kegiatan}

Kegiatan pengabdian pada masyarakat menggunakan metode dalam bentuk pelatihan keterampilan melalui penyuluhan, pelatihan/demontrasi dan diskusi dilaksanakan selama 2 minggu. Adapun tahapan-tahapan dalam pelaksanaan kegiatannya :

1. Penyuluhan, yaitu untuk penyampaian pengetahuan secara umum tentang labu kuning, yang meliputi jenis labu, nilai gizi labu kuning serta pemilihan labu kuning yang akan digunakan.

2. Pelatihan, mengenai pengembangan produk makanan dari labu kuning menjadi dodol dan roti kasur ditujukan kepada ibu-ibu kelompok tani yang tergabung dalam kelompok Usaha Kartini Mandiri di Kelurahan Parauna 
Kecamatan Anggaberi Kabupaten Konawe.

3. Demonstrasi, yaitu untuk memberikan keterampilan secara langsung mengenai proses pengolahan labu kuing menjadi dodol dan roti kasur, peralatan yang diperlukan serta bahan tambahan makanan yang digunakan dalam pengolahan. Tanya jawab digunakan untuk melengkapi hal-hal yang belum terakomodasi oleh kedua metode di atas.

4. Evaluasi hasil pelatihan dilakukan selama proses dan setelah kegiatan pelatihan dilaksanakan.

Peserta dalam kegiatan ini adalah masyarakat yang tergolong dalam Kelompok Wanita Tani (KWT) Kartini Mandiri yang berada di Kelurahan Parauna Kecamatan Anggaberi Kabupaten Konawe. Jumlah peserta pelatihan sebanyak 20 orang wanita.

\section{Metode Kegiatan yang Digunakan}

Dalam rangka mencapai tujuan yang tercantum di atas, maka ditempuh langkah-langkah sebagai berikut;

1. Menghubungi Lurah Parauna untuk mendiskusikan topik yang hendak diabdikan yaitu pemberdayaan usaha ekonomi produktif melalui pengolahan komoditas labu kuning menjadi dodol dan roti kasur bagi masyarakat petani dan mencari data jumlah warga masyarakat yang tergolong kelompok wanita tani sebagai calon peserta pelatihan

2. Menyelenggarakan pelatihan, dengan materi:

a. Kewirausahaan

b. Menemukan Peluang Usaha berbasis pangan lokal (labu kuning)

c. Manajemen usaha

d. Peningkatan keterampilan, berupa pelatihan pembuatan produk yaitu dodol dan roti kasur dari labu kuning.

\section{Keterlibatan Mitra}

Kegiatan ini tidak akan mungkin berhasil tanpa adanya keterkaitan dengan beberapa pihak lain. Dalam hal ini pihak Kelurahan Parauna Kecamatan Anggaberi Kabupaten Konawe sebagai pihak yang mempunyai wilayah di mana kegiatan Pengabdian Kepada Masyarakat hendak dilakukan, memberi dukungan dalam kegiatan ini dengan menyediakan tempat pelatihan. Diharapkan melalui program Pengabdian Kepada Masyarakat ini dapat memberikan kontribusi usaha khususnya pada wanita tani melalui pembentukan Kelompok usaha bersama maupun mandiri.

\section{Hasil dan Pembahasan}

Kegiatan pengabdian kepada masyarakat dalam bentuk pelatihan dan praktek pengolahan komoditas labu kuning menjadi dodol labu kuning dan roti kasur aneka varian isian di Kelurahan Parauna, Kecamatan Anggaberi, Kabupaten Konawe secara umum dapat dilaksanakan sesuai dengan jadwal yang direncanakan.

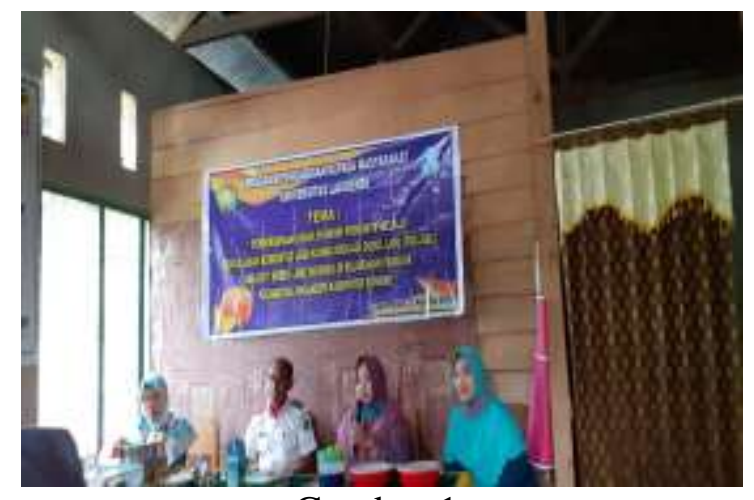

Gambar 1.

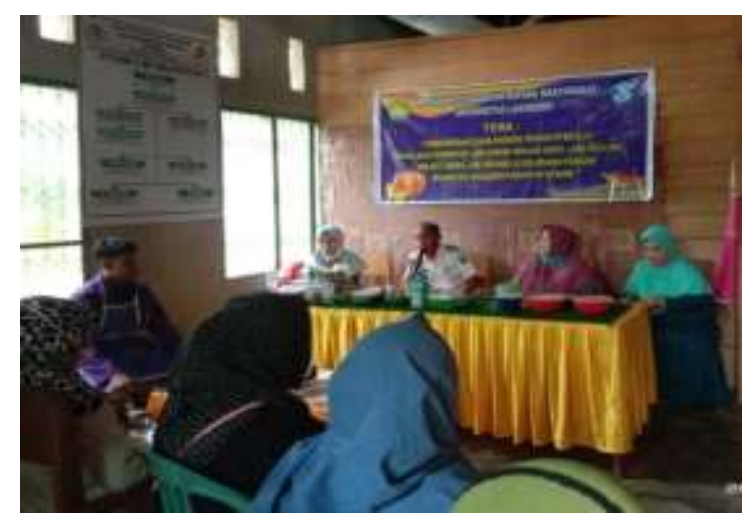

Gambar 2.

Gambar 1 \& 2. Pembukaan kegiatan Pelatihan Pengabdian Kepada Masyarakat 
Berdasarkan tujuan dari kegiatan pelatihan pengolahan komoditas labu kuning yaitu memperkenalkan dan memberikan pengetahuan dan keterampilan tambahan kepada masyarakat tentang teknologi pengolahan labu kuning menjadi dodol labu dan roti kasur sehingga masyarakat dapat mengembangkan industri rumah tangga dan meningkatkan nilai ekonomis dari labu kuning dengan memberikan penyuluhan tentang manfaat dari labu kuning disertai dengan pelatihan dan praktek membuat dodol dan roti kasur dari labu kuning.

Pelatihan ini mendapat sambutan yang sangat baik dari masyarakat khususnya Kelompok wanita tani (KWT) Kartini yang usahanya menjual panganan kue tradisional. Hal ini dapat dilihat dari tingginya antusias peserta dengan mengajukan berbagai pertanyaan, baik mengenai proses pengolahan labu kuning serta diversifikasi produk olahan labu kuning selain diolah menjadi dodol dan roti kasur sehingga terjadi diskusi dua arah yang aktif. Hal ini bisa meningkatkan pengetahuan peserta dan diharapkan dapat disebarluaskan kepada seluruh masyarakat yang ada di sekitarnya.

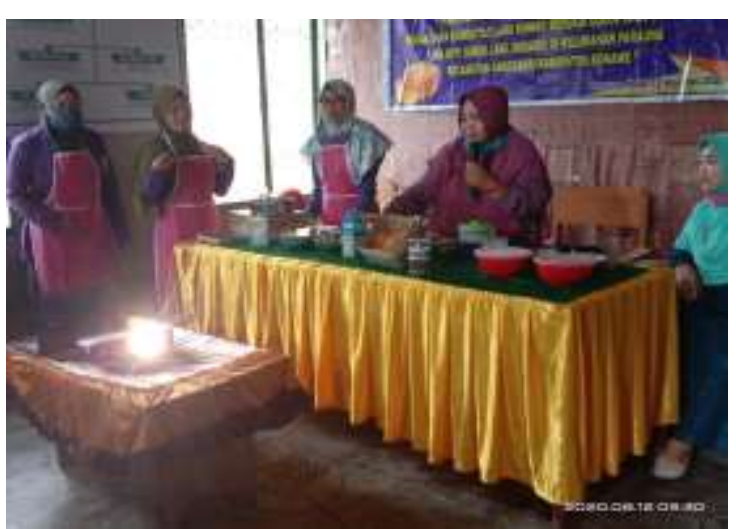

Gambar 3. Penyampaian Materi

Para peserta yang mengikuti kegiatan ini adalah ibu-ibu anggota KWT (Kelompok Wanita Tani) Kartini dengan jumlah peserta sebanyak 20 orang. Para peserta aktif dalam mengikuti kegiatan ini baik pada saat penyampaian materi, diskusi maupun saat praktek pembuatan produk. Peran aktif masyarakat ini disebabkan kare- na masyarakat Kelurahan Parauna dan Toriki yang terletak di Kecamatan Anggaberi sangat memerlukan informasi terkait dengan penerapan teknologi dalam pengolahan labu kuning menjadi dodol labu kuning dan roti kasur aneka varian isian.

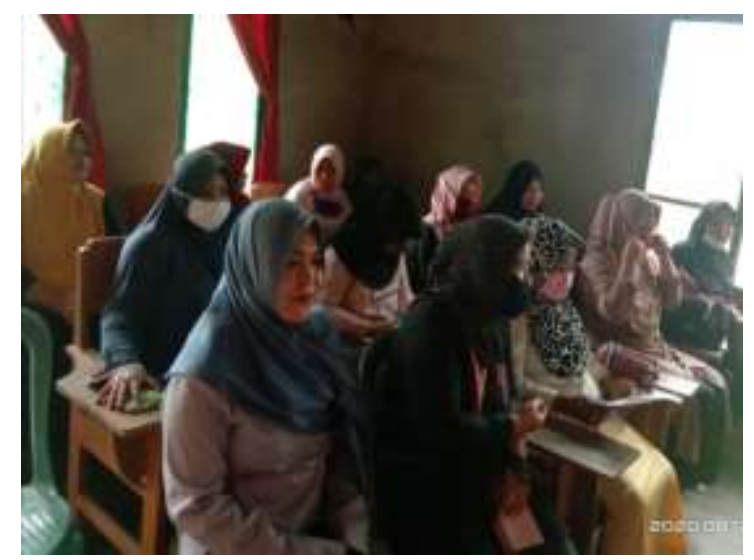

Gambar 4. Peserta Pelatihan

Tanggapan masyarakat kelurahan Parauna selaku peserta pelatihan sangat positif. Peserta pelatihan sangat antusias dalam mengikuti kegiatan ini yang ditunjukkan dari banyaknya ibu-ibu peserta yang ikut serta dalam proses praktek/demontrasi produk olahan pada saat acara kegiatan berlangsung. Mereka juga praktek langsung mengikuti arahan instruktur pelatihan untuk mengolah langsung labu kuning hingga menjadi produk berupa dodol labu kuning dan roti kasur aneka varian isian.

Masyarakat juga tertarik dengan teknologi pengolahan labu kuning menjadi dodol labu kuning dan roti kasur labu kuning disebabkan karena cara pembuatannya mudah dan peralatan yang dipergunakan juga sederhana. Kualitas produk yang dihasilkan dari kegiatan ini dapat langsung dirasakan oleh masyarakat serta adanya keinginan untuk melakukan pengolahan sendiri maupun berkelompok. Kegiatan pengabdian kepada masyarakat yang dilakukan di Kelurahan Parauna, Kecamatan Anggaberi, Kabupaten Konawe telah berjalan dengan lancar sesuai rencana. Hal ini dapat dilihat dari antusiasnya masyarakat mengikuti pelatihan ini.

Kegiatan ini tepat sasaran dengan mempraktekkan secara langsung teknologi 
pengolahan labu kuning menjadi dodol labu kuning dan roti kasur aneka varian isian kepada ibu-ibu anggota KWT Kartini Mandiri.

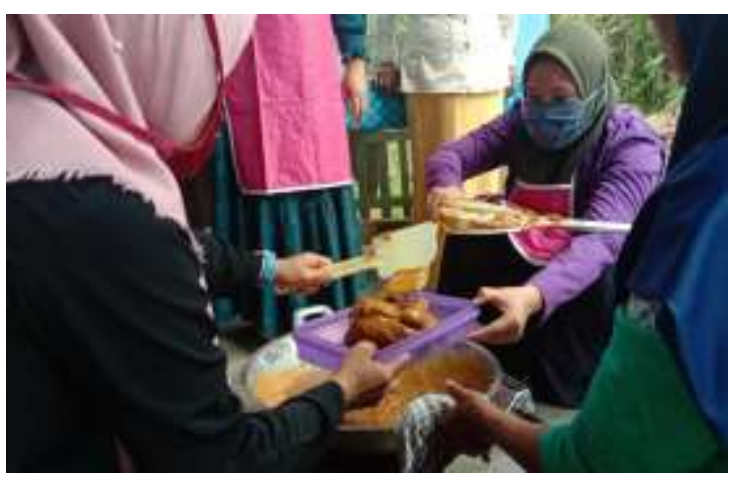

Gambar 5.

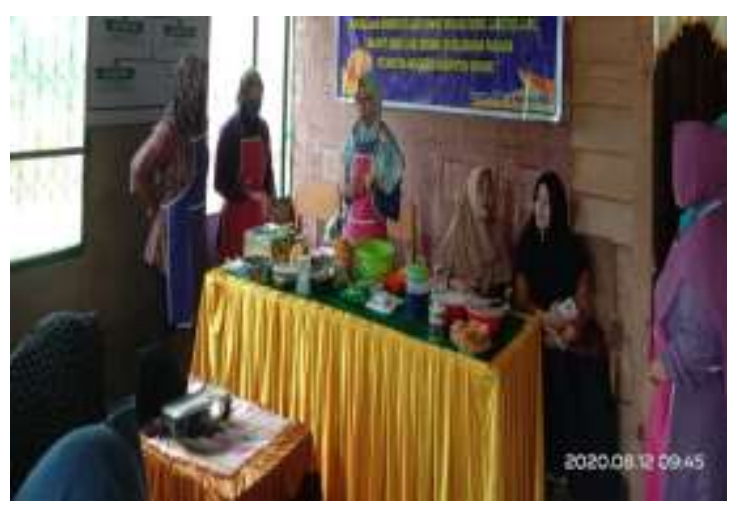

Gambar 6.

Gambar 5 \& 6. Praktek PengolahanProduk Dollabu dan Rosabu

Keberhasilan pelaksanaan seluruh kegiatan pengabdian kepada masyarakat ini tentunya mempunyai manfaat yang cukup baik bagi masyarakat pada umumnya dan pelaku industri rumah tangga khususnya. Adanya peningkatan pengetahuan masyarakat tentang pengolahan komoditas labu kuning, masyarakat dapat melakukan pengolahan sendiri sehingga dapat meningkatkan pendapatan dan kesejahteraan masyarakat.

\section{Diskusi}

Berdasarkan hasil kegiatan pelatihan pengabdian kepada masyarakat yang dilakukan ditemukan bahwa pengolahan hasil pertanian terutama diversifikasi hasil olahan pangan belum dilakukan oleh masya- rakat, biasanya setelah panen produk hasil pertanian seperti labu langsung dijual untuk dijadikan olahan sayuran, sedangkan labu kuning (labu yang sudah tua dan matang) biasanya selain untuk dijadikan sayur juga hanya dijadikan sebagai kolak.

Pelatihan pengabdian kepada masyarakat dengan menjadikan komoditas labu kuning kuning menjadi dodol labu kuning dan roti kasur dengan variasi isian memberikan wawasan pengetahuan dan keterampilan baru bagi ibu-ibu rumah tangga yang tergabung dalam Kelompok Wanita Tani (KWT) Kartini Mandiri, yang sebagian anggotanya ada usaha jajanan kue tradisional. Dengan adanya pelatihan ini, ibu-ibu rumah tangga KWT Kartini mendapatkan pengetahuan dan keterampilan baru dalam diversifikasi pangan lokal, teknik pengolahannya, desain produk dan kemasannya dan manajemen strategi pemasaran via online.

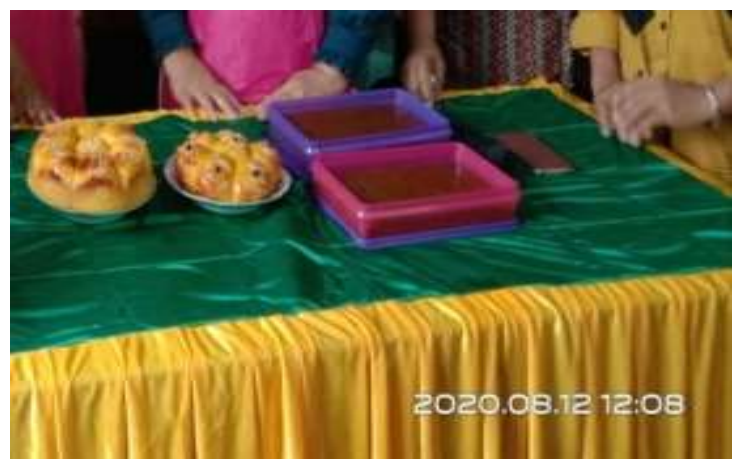

Gambar 7.

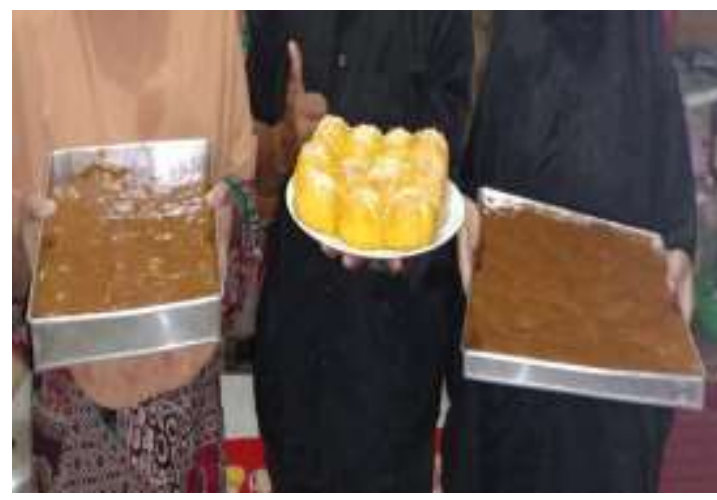

Gambar 8.

Gambar 7 \& \&. Produk hasil olahan menjadi dodol dan roti kasur 
Implikasi yang diharapkan berdampak postif bagi keluarga petani khususnya KWT Kartini Mandiri, sehingga dapat meningkatkan usaha dan pendapatan rumah tangga petani.

\section{Simpulan}

\section{Penutup}

Berdasarkan tujuan dari kegiatan pelatihan pengolahan komoditas labu kuning yaitu memperkenalkan dan memberikan pengetahuan dan keterampilan tambahan kepada masyarakat tentang teknologi pengolahan labu kuning menjadi dodol labu kuning dan roti kasur aneka variasi isian sehingga masyarakat dapat mengembangkan industri rumah tangga dan meningkatkan nilai ekonomis dari labu kuning dengan memberikan penyuluhan tentang manfaat dari labu kuning disertai dengan pelatihan dan praktek membuat dodol dan roti kasur dari labu kuning.

Keberhasilan seluruh pelaksanaan kegiatan pengabdian kepada masyarakat ini tentunya mempunyai manfaat yang cukup baik bagi masyarakat pada umumnya dan pelaku industri rumah tangga khususnya.

\section{Saran}

Melihat respon masyarakat yang tinggi terhadap pelatihan pengolahan komoditas labu kuning menjadi dodol labu kuning (Dollabu) dan roti sobek labu (Rosabu) Kelurahan Parauna, Kecamatan Anggaberi, Kabupaten Konawe maka dipandang perlu untuk melakukan kegiatan serupa di daerah-daerah lain. Kegiatan ini akan lebih bermanfaat apabila dilakukan secara simultan dengan penyuluhan mengenai pemasaran dari produk yang dihasilkan.

\section{Ucapan Terima Kasih}

Ucapan terimakasih kepada ketua KWT yang tergabung dalam kelompok usaha Kartini Mandiri dan seluruh anggota kelompok usaha Kartini Mandiri yang telah mensukseskan pelatihan pemberdayaan usaha ekonomi produktif melalui pengolahan komoditas labu kuning menjadi dodol labu kuning dan roti kasur aneka variasi isian di Parauna Kecamatan Anggaberi Kabupaten Konawe serta ucapan terima kasih kepada lurah kelurahan Parauna yang telah mendukung sehingga acara kegiatan pelatihan pengabdian kepada masyarakat dapat terlaksana dengan baik.

\section{Daftar Pustaka}

Amzar, M., Hendayana, S., Wahyu, W., Supriatna, A., Lestiyani, S., Collaborative Lesson Design of Acid-Base Titration Curve in Indonesia Senior High School, International Conference on Mathematics and Science Education of Universitas Pendidikan Indonesia Vol. 3, 2018

Astawan, Made. 2005. Info Teknologi Pangan department of Food Science and Technology. Faculty of Agricultural Tecnology and Enginering, Bogor Agricultural University.

Direktorat Gizi Depkes RI. 2004. Daftar Komposisi Bahan Makanan. Bhratara Karya Aksara, Jakarta.

Haryadi. 2006. Teknologi Pengolahan Beras. Universitas Gadjah Mada Press. Yogyakarta.

Heliyani, H.D. 2012. Penegembangan Produk Pangan Berbahan Baku Labu Kuning. Jurnal Peningkatan Daya Saing Pangan Tradisional. Vol 2 No. 1 Diaskes pada bulan maret 2013.

Mahmud dkk. 2008. Tabel Komposisi Pangan Indonesia (TKPI). Jakarta: Alex Media Komputindo.

Radyaswati. 2005. Penggunaan Labu Kuning dalam Pembuatan Saos Sambal. Jurusan Teknologi Pangan dan Hasil Pertanian Fakultas Teknologi Pertanian. UGM, Yogyakarta.

Rahmawati L, Susilo B, Yulianingsih R. 2014. Pengaruh variasi Blanching Dan Lama Perendaman Asam Asetat (CH3COOH) Terhadap Karakteristik Tepung Labu Kuning 
Termodifikasi. Jurnal Bioproses

Komoditas Tropis 2(2): 107-115.

Satuhu, S., dan Sunarmani. 2004. Membuat Aneka Dodol Buah. Penebar Swadaya, Jakarta. 